\title{
Education Analysis and Entrepreneurship Training For Micro, Small and Medium Enterprises (SMEs) in Sentra Tenun Ikat Lamongan Regency
}

\author{
Sulistyo \\ Sholikhan \\ Sri Rahayuningsih \\ Study Program of Accounting Kanjuruhan University \\ Study Program of Physics Education Kanjuruhan University \\ Study Program of Guidance and Counseling Kanjuruhan University \\ Email: phibinusi@gmail.com
}

\begin{abstract}
The purpose of this study is to describe management education and entrepreneurship training for craftsmen tenun ikat in Lamongan regency. The type of research used is descriptive qualitative which data collection using interview and documentation techniques. Data analysis consists of data reduction, data presentation, and conclusion. The results showed that education and training management began with the planning and determination of training participants, analysis of training needs of the participants, the determination of the goals and objectives of the training and the determination of program content. Implementation of entrepreneurship training plays a role in forming motivation and entrepreneurial intentions for craftsmen tenun ikat in Lamongan regency. It is necessary to evaluate the implementation of the training which is implemented within 4-5 months after the implementation of the training, with the aim to know the development of business owned by participants who have followed the training.
\end{abstract}

Keywords: Education and Entrepreneurship Training; craftsmen tenun ikat

Development and growth of the national economy will be realized if there is cooperation between central government and local government (Rossignoli, et al., 2015; Panya, et al 2017). Local governments are tasked with building their regional potentials in accordance with the provisions of the central government. Local governments can develop their regional potentials by realizing through micro-economic development efforts (Rougier, et al., 2018). The existence of micro-economy that is developing in the area today is Micro Small and Medium Enterprises (MSMEs). SMEs as one of micro business can contribute to building local economic potential through the development of people's creativity in entrepreneurship (Miao, et al., 2017).

The development of SMEs in Indonesia has become the backbone of the people's economic system that can reduce the problem of the gap between groups and between business actors, and can play a role in poverty alleviation (Munizu, 2010). There are seven sectors in the business of SMEs (Bank Indonesia, 2015) namely (1) trade sector; (2) processing industry sector; (3) agricultural sector; (4) plantation sector; (5) livestock sector; (6) fisheries sector; and (7) the service sector. These SMEs sectors are widespread in areas in Indonesia that can absorb more labour through labour intensive and can also contribute to regional revenues that will impact on the national income that has been dominated by large companies and capital intensive (Kristiyanti, 2012). 
SMEs are faced with many problems such as difficulties in obtaining information and operational access (Irjayanti \& Aziz, 2012) such as difficulties in product marketing, product distribution, structural issues of establishment and operation of enterprises, and lack of capital assistance from capital institutions caused by distrust on SMEs that are not in the form of legal entities (Bank Indonesia). In general, the problems that occur are the lack of creativity (Irjayanti \& Aziz, 2012) and the low entrepreneurial spirit possessed by Human Resources (HR) as the main actors in SMEs (Eravia, et al., 2015).

Various problems that occur cause someone less desire to entrepreneurship. The desire or intention of someone to entrepreneurship is called entrepreneurship intention (Sánchez \& Sahuquillo, 2017). In general, the intentions of entrepreneurship are influenced by internal and external factors. Internal factors are factors that come from within a person, among others: self-confidence, the need for achievement, creativity, independence, and the courage to take risks. While external factors are factors that come from outside, such as subjective norms (support others), social environment, and educational environment (Wahyono, 2013).

The actors of SMEs with the intention to start a business will have better readiness and progress in the business run than someone without the intention to start their business (Sánchez \& Sahuquillo, 2017; Koe, et al., 2015). building entrepreneurial intentions on SMEs can be pursued through entrepreneurship education. The entrepreneurship education provided for SMEs is conducted by non-formal education institutions in cooperation with local governments.

Entrepreneurship education for SMEs sectors is useful to form SMEs actors to better understand about entrepreneurship (Sánchez \& Sahuquillo, 2017). Complementing the knowledge and skills already possessed, SMEs actors are also equipped with entrepreneurship training through practice directly. The perpetrators of SMEs who have received knowledge of entrepreneurship are expected to form an entrepreneurial intention in the form of a desire to create a new business or develop a business that has been owned (Koe, et al., 2015).

In accordance with the Law no. 20 of 2008 Article 19 on Small and Medium Micro Enterprises that local governments have the task of facilitating the development of MSMEs in the field of human resources by establishing and developing educational institutions and training to conduct education, training, counselling, motivation and creativity, and for the creation of entrepreneurs new. Based on the explanation of the Act, the local government of Lamongan District in cooperation with related offices and universities provide entrepreneurship education and training for MSMEs in Lamongan District craftsmen tenun ikat in Meduran District. Implementation of education and entrepreneurship training in accordance with one of the functions of the Department of Cooperatives and SMEs is conducting coaching, development, control, and supervision in the field of cooperatives and SMEs (Renstra Dinas KSMES, 2014: 9).

Craftsmen tenun ikat in Meduran District of Lamongan Regency almost 60\% of its people rely on this creative craft sector. In this village, there are 50 groups of ikat woven craftsmen who only produce sarongs. Limitations of the resulting product are causing demand from consumers is also limited at certain times. Development by Dinas Koperasi and SMEs Lamongan has been done but still not maximal.

The large number of craftsmen tenun ikat in Lamongan district is faced with various problems, among others: the emergence of many new entrepreneurs in rural areas that are not identified, making it difficult in coaching; still weak publication of 
weaving products in terms of promotion and marketing; the lack of new entrepreneurship creation is caused by the mindset of the entrepreneurial spirit is still low; as well as the weak understanding of handicraft artisans on business licenses (Renstra Dinas KSMES, 2014: 26-27). To overcome these problems, SMEs Lamongan District in cooperation with the University of Kanjuruhan do more intensive coaching through education and entrepreneurship training for weaving craftsmen in Lamongan regency.

Department of Cooperatives and SMEs Lamongan has been carrying out development through entrepreneurship education and training for artisans weaving since 2005. This formation is also carried out by the University Kanjuruhan through Science and Technology for Society program funded by Kemenristekdikti. Coaching through training that has been done the results have been good but not maximal. In the evaluation conducted after the training, still found some troubled craftsmen so that his business cannot develop. Therefore, in addition to conducting intensive training through training, the team of Kanjuruhan University regularly monitors for craftsmen weaving to know the development of its business.

This research is expected to make a positive contribution for Department of Cooperatives and SMEs in Lamongan, craftsman tenun ikat, and further researcher as a reference for the analysis of education and entrepreneurship training for MSMEs.

\section{METHODS}

The research approach used in this research is descriptive qualitative. The presence of researchers in the field is a key instrument of research implementation. Location of research at SMEs in Setra Tenun Ikat Maduran District of Lamongan Regency. Informants in this study include Chairman of the community of artisans in the centre of ikat weaving, Head Section Promotion \& Development SMES Kab. Lamongan, and 5 participants of entrepreneurship training. Research procedures for data collection using interviews and documentation studies. The stage of analysis performed is data reduction, data presentation, and data verification. Methods of checking the validity of data used in this study include increased perseverance, triangulation of sources, and using reference materials. The research phase includes preparation phase, implementation phase, and reporting phase.

\section{RESULT \& DISCUSSION}

\section{Result}

The training plan is divided into several stages, among others: (1) determination of training candidate, (2) needs analysis of training candidate, (3) determination of training objectives and objectives, (3) determination of training program content ie selection of a resource, material, and training methods. The determination of training applicants and needs analysis is determined based on the needs of SMEs at Sentra Tenun Ikat Kab. Lamongan to provide skills, develop talents, diversify products so as to develop weaving business and create new job opportunities for the community. The speaker who delivered the material at the time of training from the State University of Malang and the University of Kanjuruhan Malang. The types of training exercises that are given at the time of training vary, according to the needs and talents possessed by the participants. 
During the implementation of the training, the research team provided facilities for the training participants in accordance with the entrepreneurship training provided. The facilities are provided for the purpose of assisting the training participants in opening a new business or developing a business they already have. In the implementation of entrepreneurship training, there are supporting and inhibiting factors of training implementation. The supporting factors for the implementation of the training are: the desire of the training participants to own the business and develop the business, and the number of proposals submitted by the community for the implementation of the training, while the impeding factor of the training implementation is the limited budget from the government for the implementation of the training because the budget is used for the development of SMEs.

The research team evaluated the training about 4-5 months after the training. At the time of the evaluation, the team collects information from training participants in the form of business development. The evaluation was conducted with the aim to measure the effectiveness of the implementation of the training program and assess the development of business owned by participants who have followed the training, by conducting a survey on each business location. Through the monitoring done is expected, the business owned well developed. In addition, the provision of facilities from the team through community service programs in the form of production equipment also increasingly support the development of the business.

\section{Discussion}

The importance of SMEs training and assistance in Sentra Tenun Ikat Lamongan Regency is very helpful for craftsmen in developing their business (Katz, 2003), especially this handicraft is a craft declined that became the regional superior product. It is right for this effort to be part of the regional economic development policy.

The effectiveness of the training implementation is influenced by the models and methods used in the training objectives so that participants can easily understand the materials and training provided (Roffe, 2010). Kamil (2012: 35) explains that the training model that can be applied as a non-formal education such as apprenticeship training; model of internship training; job training model; literacy training model; entrepreneurship training model; and quality management training. The training model applied to the training held at SMEs craftsman tenun ikat in Lamongan is entrepreneurship training model, because it is based on the needs of the training participants in terms of talent development and entrepreneurship skills.

The method of training is an approach how to the implementation of the training to develop the cognitive, affective and psychomotor aspects of training participants. The training method used in entrepreneurship training for SMEs craftsman tenun ikat in Lamongan Regency is lecture and demonstration. The training program is basically a specially planned program with the aim to build knowledge and skills and to enhance entrepreneurship motivation. This is in line with research conducted by Rosianti et al. (2014) that the efforts of the Department of Cooperative SMEs in organizing education and entrepreneurship training to improve motivation and entrepreneurship intentions have been good, as evidenced by the decision of the training participants to open and develop the business. 
This entrepreneurship training is held to train and develop the skills of trainees in entrepreneurship and to foster entrepreneurship intentions. People who already have certain skills will be given entrepreneurship training and facilities in the form of tools and materials needed. This is done in the hope of the reciprocal of the community to better master the skills possessed after following the entrepreneurship training. The contribution of participants in the follow-up training is not expected to be interested in the facilities, grants, or allowance provided, but to develop the talent possessed by the participants. With the contribution and seriousness of the participants, the goal of training to establish the entrepreneurial intention of training participants can be realized. In the implementation of entrepreneurship training, the Department of Cooperatives and SMEs Lamongan Regency in cooperation with Universities, this cooperation is done with the aim to provide experienced speakers and trainers. Experienced trainers and trainers play an important role in the implementation of the training to support the success of the training, especially the provision of business motivation with the aim to improve the knowledge, skills and behaviour of the training participants to be motivated to start a new business.

A training program can be said to be successful if the training participants are able to follow the training well and can apply the skills acquired after following the training. Monitoring and evaluation conducted to assess and measure the achievement of the training objectives and to monitor the development of training participants business. Implementation of training evaluation can be done at the beginning of planning, in the middle of implementation, at the end of implementation, and after the implementation of the training. The relevant evaluation model to be implemented in training evaluation organized by government agencies in non-formal education is a "five-stage evaluation" model initiated by Batchelor (in Supriyono, 2013: 26). The five stages of the evaluation are: at the end of the training, 1-3 months after the training, 1 to 6 months after the training, 6 months after the training, and 1 year after the training.

Based on the evaluations that have been done, found some training participants who previously have embryo business tend to experience the development of the business. These developments include increased production, marketing expansion, acceptance of neighbours as employees and so forth, whereas previously unemployed training participants were encouraged to open new businesses in accordance with the training that followed.

In addition to coaching in terms of implementation of the training, Department of Cooperatives and SMEs Lamongan District also perform training post-training for training participants. Coaching conducted after the training is done if found problems during the evaluation and monitoring. The problem is, for example, there are training participants who have the skills to entrepreneurship but have constraints to open a new business or develop a business that has been owned. To overcome these problems, Department will conduct post-training and training by conducting the joint evaluation, providing direction, and helping to find solutions.

Implementation of education and entrepreneurship training for business actors can play an important role to form a person to have the intention of entrepreneurship in the form of a desire to take advantage of existing business opportunities by opening and developing business. Entrepreneurship training program can improve entrepreneurship intention of training participants in Lamongan regency. Through entrepreneurship training, training participants get the knowledge and experience they have never gained. In addition to growing entrepreneurship intentions, the training experience is also 
realized by the participants by starting and developing the business. That the entrepreneurship training program plays a role in shaping the entrepreneurial intention (Wibowo \& Pramudana, 2016) in the form of the desire of the trainees to start and develop the business and see other business opportunities that can be run.

\section{CONCLUSION AND SUGGESTION}

\section{Conclusion}

Based on the findings of research and discussion, the researchers can draw conclusions on the planning, implementation, evaluation, and role of entrepreneurship training. Evaluation of the training done within 4-5 months after the training. The evaluation is conducted with the objective of (1) to assess the implementation of the training in accordance with the objectives of the training and (2) to know the effectiveness of the training participants in the development of the business being carried out. The role of entrepreneurship training for the weaving artisans Lamongan Lamongan, among others, can form the intention of entrepreneurship in the form of the desire of the trainees to start and grow the business, and see other business opportunities that can be run.

\section{Suggestion}

Evaluation of the implementation of the training should be done continuously in order to intensively assess the implementation of the training starting from the action plan after the training, measuring the participants' memories after attending the training, applying the learning outcomes, measuring the results of the business, and the efficiency of the training program. For entrepreneurship training participants, that training participation should be based on the intention and desire to develop talent through the training provided, as well as the knowledge and entrepreneurship skills acquired at the time of the training should be applied to pioneer new business, or to develop the business owned. Third, for the next researcher, that in this research there are limitations of research that researchers only do an interview with one informant on each type of training.

\section{REFERENCES}

Bank Indonesia. 2011. Academic Review Credit Rating for Micro, Small and Medium Enterprises in Indonesia. Bank Indonesia. (Online), (http://www.bi.go.id/id/SMEs/penelitian/nasional/kajian/Documents/7da49f 82a34f4bd4bde57ba94172a0b3BukuKajianAkademikKelayakanPendirianLem bagaPemerin.pdf), accessed 05 November 2016. (Indonesian Origin).

Bank Indonesia. 2015. Business Profile of Micro, Small and Medium Enterprises (SMEs). Indonesian Banking Development Institute. (Online), (http://www.bi.go.id/id/SMEs/penelitian/nasional/kajian/Documents/Profil \%20Bisnis\%20SMES.pdf), accessed 05 November 2016. (Indonesian Origin).

Departement of Cooperative and SMES Lamongan Regency. 2014. Strategic Plan of Department of Cooperatives and SMEs 2014-2018. Dinas Koperasi and Micro Small and Medium Enterprises of Lamongan Regency. (Online), 
(http://jombangkab.go.id/upload/1444617235 renstra\%20dinkop\%20SMEs \%202014-2018.pdf), accessed 04 November 2016. (Indonesian Origin).

Eravia, D., Handayani, T., Julina. 2015. The Opportunities and Threats of Small and Medium Enterprises in Pekanbaru: Comparison between SMEs in Food and Restaurant Industries. Procedia Social and Behavioral Sciences. Volume 169, 20 January 2015, Pages 88-97. (Indonesian Origin).

Irjayanti, M., Azis, A.M. 2012. Barrier Factors and Potential Solutions for Indonesian SMEs. Procedia Economics and Finance. Volume 4, Pages 3-12.

Katz, J.A.2003. The chronology and intellectual trajectory of American entrepreneurship education. Journal of Business Venturing. 18 (2003) 283-300.

Kamil, M. 2012. Education and Training Model (Concepts and Applications).Bandung: Alfabeta. (Indonesian Origin).

Koe, W.L., Omar, R., Sa'ari, J.R. 2015. Factors Influencing Propensity to Sustainable Entrepreneurship of SMEs in Malaysia. Procedia Social and Behavioral Sciences Volume 172, 27 January 2015, Pages 570-577.

Kristiyanti, M. 2012. The Strategic Role of Small and Medium Enterprises (SMEs) in National Development. Scientific Magazine Informatics, (Online), 3 (1):63-89, (http://www.unaki.ac.id/ejournal/index.php/majalah-ilmiah-

informatika/article/view/59/9526, accessed November 2016. (Indonesian Origin).

Miao, C., Rutherford, M.W., Pollack, J.M. 2017. An Exploratory Meta-Analysis of the Nomological Network of Bootstrapping in SMEs. Journal of Business Venturing Insights. Volume 8, November 2017, Pages 1-8.

Munizu, M. 2010. The Influence of External and Internal Factors on the Performance of Micro and Small Enterprises (MSEs) in South Sulawesi. Journal of Management and Entrepreneurship, Volume 12 (1): 33-41. (Indonesia original).

Nursito \& Nugroho. 2013. Analysis of the Effects of Entrepreneurship Knowledge Interaction and Self-Efficacy on Entrepreneurial Intentions. BUSINESS Tips, (Online), $\quad 5 \quad$ (2): (http://id.portalgaruda.org/?ref=browse mod=viewjournal\&journal=6821\&is sue $=\% 20$ Vol\%205,\%20No\%202\%20(2013):\%20Kiat\%20BISNIS\%20Juni), accessed April 18, 2017. (Indonesian Origin).

Panya, N., Poboon, C., Phoochinda, W., Teungfung, R. 2017. The performance of the environmental management of local governments in Thailand. Kasetsart Journal of Social Sciences. In Press, Pages 1-9.

Roofe, I. 2010. Sustainability Of Curriculum Development For Enterprise Education. Education \& Training. Vol. 52 No. 2, pp. 140-164 
Rougier, E., Combarnous, F., Fauré, Y.A. 2018. The "Local Economy" Effect of Social Transfers: An Empirical Assessment of the Impact of the Bolsa Família Program on Local Productive Structure and Economic Growth. World Development. Volume 103, March 2018, Pages 199-215

Rosianti, dkk. 2014. Efforts of the Cooperative SME Office in Organizing Education and Training of Entrepreneurship To Improve Entrepreneurship Motivation (Study On Cooperative Service, SME, Industry, Trade, and ESDM Sidoarjo). Journal of Business Administration. (On line), 12 (1): 1-8, (administrasibisnis.studentjournal.ub.ac.id/index.php/jab/article/view/488), accessed April 18, 2017. (Indonesian Origin).

Rossignoli, S., Coticchia, F., Mezzasalma, A. 2015. A Critical Friend: Monitoring and Evaluation Systems, Development Cooperation and Local Government. The Case of Tuscany. Evaluation and Program Planning. Volume 50, June 2015, Pages 6376.

Sánchez, V, B., Sahuquillo, C.A. 2017. Entrepreneurial Intention Among Engineering Students: the Role of Entrepreneurship Education. European Research on Management and Business Economics. Article In Press, Pages 1-9.

Supriyono. 2013. Program Evaluation for Education and Training. Malang: Faculty of the Education Science State University of Malang. (Indonesian Origin).

Wahyono, B. 2013. The Effect of Entrepreneurship Education on Student Entrepreneurship Student SMK Negeri 1 Pedan Year 2013, (Online), (https://eprints.uns.ac.id/11579/1/337592512201307582.pdf), accessed March 30, 2017. (Indonesian Origin).

Wibowo, S., Pramudana, K.A.S. 2016. The Effect of Entrepreneurship Education on the Intelligence of Entrepreneurship Which is mediated by Entrepreneurship Attitude. E-Journal of Management Unud. Vol. 5, No. 12, 2016: 8167-8198 (Indonesian Origin). 